\title{
Prediction of Cheatgrass Field Germination Potential Using Wet Thermal Accumulation
}

\author{
Bruce A. Roundy, ${ }^{1}$ Stuart P. Hardegree, ${ }^{2}$ Jeanne C. Chambers, ${ }^{3}$ and Alison Whittaker ${ }^{4}$
}

Authors are ${ }^{1}$ Professor, Wildlife and Wildlands Conservation Program, Department of Plant and Wildlife Sciences, Brigham Young University, Provo, UT 84602; ${ }^{2}$ Plant Physiologist, USDA Agricultural Research Service, Northwest Watershed Research Center, Boise, ID 83712; ${ }^{3}$ Research Ecologist, USDA Forest Service, Rocky Mountain Research Station, Reno, NV 89512; and ${ }^{4}$ Wildlife Biologist, Utah Division Wildlife Resources, Ephraim, UT 84627.

\begin{abstract}
Invasion and dominance of weedy species is facilitated or constrained by environmental and ecological factors that affect resource availability during critical life stages. We compared the relative effects of season, annual weather, site, and disturbance on potential cheatgrass (Bromus tectorum L.) germination in big sagebrush (Artemisia tridentata Nutt.) communities. Soil water status and temperature in the seedbed were measured continuously for 4 years on 9 big sagebrush sites in Nevada and Utah. Field plots at lower-, middle-, and upper-elevation sites were either undisturbed, or were burned, sprayed with herbicide, or both sprayed and burned. Spraying removed perennial herbaceous vegetation, whereas burning removed sagebrush. We used thermal-germination data from laboratory incubation studies of 18 cheatgrass seedlots and field soil moisture and temperature measurements to model and predict potential germination in the field plots for periods when seedbeds were continuously wet (above $-0.5,-1$, or $-1.5 \mathrm{MPa}$ ) and across intermittent wet and dry periods. Season had the greatest effect on potential cheatgrass germination, followed by annual weather, and site variables (elevation and location); the effects of disturbance were minimal. Potential germination was predicted for most sites and years in spring, a majority of sites and years in fall, and few sites or years in winter. Even though disturbance has limited effects on potential germination, it can increase cheatgrass invasion and dominance by reducing perennial herbaceous species resource use and allowing increased cheatgrass growth and reproduction.
\end{abstract}

\section{Resumen}

La invasión y dominancia de las malezas es facilitada o dificultada por factores ambientales y ecológicos que afectan la disponibilidad de recursos durante las etapas críticas del ciclo de vida. Comparamos los efectos relativos de la estación, clima anual, sitio, y disturbio sobre la germinación potencial del "Cheatgrass" (Bromus tectorum L.) en comunidades de "Big sagebrush" (Artemisia tridentata Nutt.). La temperatura y el estado del agua en el suelo se midieron continuamente en la cama de siembra por cuatros años en 9 sitios de "Big sagebrush" en Nevada y Utah. Las parcelas de campo en los sitios de elevaciones baja, media, y alta recibieron alguno de los siguientes tratamientos: sin disturbio, quemados, asperjados con herbicidas, o quemados y asperjados con herbicidas. La aspersión de herbicida removió la vegetación herbácea perenne, mientras que la quema removió el "Sagebrush." Usamos datos de temperatura-germinación de estudios de incubación en laboratorio de 18 lotes de semilla de "Cheatgrass" y las mediciones de campo de temperatura y humedad del suelo para modelar y predecir la germinación potencial en las parcelas de campo en periodos cuando las camas de siembra estuvieron continuamente húmedas (arriba de $-0.5,-1, \mathrm{o}-1.5 \mathrm{MPa}$ ) y durante periodos intermitentes secos y húmedos. La estación tuvo el efecto más fuerte sobre la germinación potencial del "Cheatgrass," seguida por el clima anual y las variables del sitio (elevación y localización); que los efectos del disturbio fueron mínimos. En primavera, la germinación potencial se predijo para la mayoría de los sitios y años, en otoño, para un gran número de sitios y años, y en invierno para pocos sitios y años. A pesar de que el disturbio tuvo efectos limitados sobre la germinación potencial, esta condición puede aumentar la invasión y dominio del "Cheatgrass" al reducir es uso de los recursos por especies herbáceas perennes y permitir un mayor crecimiento y reproducción del "Cheatgrass."

Key Words: big sagebrush, disturbance, fire, Great Basin, heat accumulation, soil temperature, soil water, thermal-germination models, weed invasion

\section{INTRODUCTION}

Cheatgrass (Bromus tectorum L.) has spread across the Intermountain West since its introduction in the late 1880 s

Research was funded in part by the Joint Fire Sciences Program (00-2-15) and Brigham Young University professional development funds.

Mention of a proprietary product does not constitute a guarantee or warranty of the product by USDA or the authors and does not imply its approval to the exclusion of other products that also may be suitable.

Correspondence: Bruce A. Roundy, Dept of Plant and Wildlife Sciences, Brigham Young University, Provo, UT 84602. Email: bruce_roundy@byu.edu

Manuscript received 30 November 2005; manuscript accepted 1 August 2007.
(Mack 1986). Its current dominance on rangelands once occupied by big sagebrush (Artemisia tridentata Nutt.) has decreased ecological values and greatly increased the frequency of catastrophic wildfire in this region (Billings 1990; D'Antonio and Vitousek 1992). Because of their extent and location, Wyoming big sagebrush (Artemisia tridentata Nutt. subsp. wyomingensis Beetle and Young) communities in the Great Basin are especially susceptible to invasion by cheatgrass and other annual weeds (Wisdom et al. 2005). Higher elevation mountain big sagebrush (Artemisia tridentata Nutt. subsp. Vaseyana [Rydb.] Beetle) communities are also considered to be at risk to invasion, but are less extensive than Wyoming big sagebrush communities and have exhibited less invasion 
(Wisdom et al. 2005). Cheatgrass invasion produces an abundance of fine fuels, lengthens the dry period, and results in an annual-dominated steady state that is sustained by increased fire frequency (Whisenant 1990; Knapp 1996; Brooks and Pyke 2001).

Resource availability greatly influences weed invasion and dominance (Chambers et al. 2007). An understanding of the effects of disturbance on resource availability during critical weed life stages and within the climatic context of the environment at risk should help focus weed management strategies. Cheatgrass is able to exist in undisturbed plant communities (Douglas et al. 1990; Rice and Mack 1991; Valentine and Stevens 1994; Meyer et al. 2001; Chambers et al. 2007) but maintenance of mature perennial herbaceous vegetation can reduce the potential for cheatgrass dominance (Stevens 1997; Booth et al. 2003; Beckstead and Auspurger 2004; Humphrey and Schupp 2004; Chambers et al. 2007). Weed invasion is considered most likely in systems where climatic conditions or disturbance yield the environmental resources required for germination, growth, and seed production of invasive species (Davis et al. 2000). Resource availability can also determine the extent of dominance of annual species such as cheatgrass that have high potential for growth and seed production. On a large scale, climate is a major determinant of what bioregions are susceptible to cheatgrass invasion, whereas disturbance can dictate the extent of invasion in a susceptible bioregion such as the sagebrush steppe (Bradford and Lauenroth 2006). Disturbance that removes understory perennial herbaceous species greatly increases cheatgrass growth and reproduction in big sagebrush communities of the Great Basin (Chambers et al. 2007).

What is the role of germination in cheatgrass invasion relative to resource availability? Cheatgrass seeds are wellsuited to take advantage of available resources. After a dry afterripening period in summer (Meyer et al. 1997), cheatgrass seeds germinate over a wide range of temperatures (Martens et al. 1994). Previous authors have measured cheatgrass germination as a function of thermal and hydrotime accumulation, or as time spent above threshold values of temperature and water potential (Christensen et al. 1996; Bauer et al. 1998; Hardegree et al. 2003; Taylor et al. 2004, 2007; Bair et al. 2006). The ability to germinate rapidly at low temperature has been proposed as one mechanism by which cheatgrass successfully competes with native perennial grasses for soil moisture in the fall, winter, and early spring (Wilson et al. 1974).

Is disturbance necessary for cheatgrass germination in Great Basin big sagebrush communities? The purpose of our study was to estimate potential germination response of cheatgrass to temperature and water-potential thresholds in the field to determine the relative effects of disturbance compared to factors such as site, season, and annual weather, which make up much of the physical environmental context of these communities. This was done by using field-measured soil temperatures and water potentials to calculate progress toward germination based on laboratory response of cheatgrass germination rate to temperature. Because disturbance can influence soil temperatures and water potentials, it has the potential to influence cheatgrass germination. We hypothesized that seasonal temperatures and water potentials are generally adequate for cheatgrass germination in Great Basin big sagebrush plant communities and that germination is therefore not dependent on disturbance.

\section{METHODS}

\section{Study Sites}

Soil water status and soil temperature were measured on 4 sites in Nevada and 4 sites in Utah, as described in detail by Chambers et al. (2007), with an additional site in Utah dominated by squirreltail grass (Elymus elmoides [Raf.] Swezey). Study sites were located along elevation gradients within drainages dominated by Wyoming big sagebrush at lower elevation and mountain big sagebrush at middle and upper elevation. These sites were either in good condition (7 sites) or seeded to crested wheatgrass (Agropyron cristatum [L.] Gaertn.; 2 sites). Soils at the Nevada crested wheatgrass-, lower-, and middle-elevation sites are sandy loam; at the Nevada upper-elevation site they are loam to sandy loam. Soils at the Utah crested wheatgrass- and lower-elevation sites are gravelly coarse sandy loam; at the Utah squirreltail site they are coarse loam; at the Utah middle-elevation site they are gravelly coarse loam; and at the Utah upper-elevation site they are very gravelly coarse loam.

\section{Experimental Treatments}

Vegetation removal and burn treatments were applied in a factorial design to examine the separate and combined effects of perennial herbaceous vegetation removal and fire on seedbed temperature and moisture. Individual study plots (3.4-m diameter) were located within each of the shrub-dominated study sites around individual sagebrush plants and were usually separated by $\geq 2 \mathrm{~m}$. Crested wheatgrass and squirreltail study plots were located within areas of relatively uniform grass cover. Vegetation treatments included leaving the herbaceous understory intact (live) or spraying with glyphosate (Roundup $^{\circledR}$ ) herbicide in spring of 2001 for complete kill (dead). Burn treatments were applied in fall 2001 and consisted of placing 3.4-m diameter barrels around each plot, adding $4.5 \mathrm{~kg}$ of straw to improve fuel consistency, and igniting the straw and initial vegetation with a drip torch (Korfmacher et al. 2003). Three replicates of each treatment combination were applied per site $(9$ sites $\times 2$ herbicide treatments $\times 2$ burn treatments $\times 3$ replicates $=108$ plots).

\section{Seedbed Environmental Monitoring}

In summer 2001, thermocouples were buried at a depth of 1$3 \mathrm{~cm}$ in 2 replicate plots of each treatment combination. Gypsum blocks (Delmhorst, Inc.) were buried at a similar depth in 3 replicate plots of each treatment combination. Thermocouple and gypsum-block output were read every minute and hourly averages were recorded using Campbell Scientific, Inc. CR-10X microloggers. Soil water potentials down to $-1.5 \mathrm{MPa}$ were estimated from gypsum block electrical resistance using a standard calibration curve (Campbell Scientific, Inc. 1983). Hourly air temperature was measured from a thermister in a gill shield, and total hourly precipitation was monitored from an electronic tipping bucket rain gage at 
each study site. Measurements for this study were recorded from fall 2001 through spring 2005.

\section{Thermal Accumulation Responses}

Times to $25 \%$ and $50 \%$ germination of total germinable seeds (the subpopulations of seeds that germinate faster than the remaining $75 \%$ and $50 \%$ of seeds) were measured at 11 temperatures in $3^{\circ} \mathrm{C}$ increments between $3{ }^{\circ} \mathrm{C}$ and $33^{\circ} \mathrm{C}$ for 8 populations of cheatgrass collected for 1-2 years (15 total seedlots) from Idaho, Washington, Nevada, and British Columbia using methods described by Hardegree (2006). Germination times for the same subpopulation percentiles were also tested for 3 populations collected from Utah and incubated at 6 constant temperatures in $5^{\circ} \mathrm{C}$ increments between $5^{\circ} \mathrm{C}$ and $30^{\circ} \mathrm{C}$ using methods of Roundy and Biedenbender (1996). Germination rate $\left(\mathrm{d}^{-1}\right)$ of the $25 \%$ and $50 \%$ subpopulations was estimated for all seedlots as a function of incubation temperature using nonlinear regressions derived with the TableCurve ${ }^{\circledR}$ 2D curve-fitting program (Systat Software, Inc.) as described by Hardegree (2006). Curvilinear equations with best fit and lowest residuals were selected for each seedlot within the measurement range. $R^{2}$ values for these curves ranged from to 0.74 to 0.99 , with 23 of the 36 curves having an $R^{2}>0.90$. Germination rates below the lowest measured temperature response were estimated using linear regression of the lowest 2 measured rates $\left(3^{\circ} \mathrm{C}\right.$ and $6^{\circ} \mathrm{C}$ for 15 seedlots and $5^{\circ} \mathrm{C}$ and $10^{\circ} \mathrm{C}$ for 3 seedlots). For rates above the highest measured temperatures, germination rates were estimated by the curvilinear equations up to $38^{\circ} \mathrm{C}$, above which they were set to zero.

Progress toward germination (PTG; Roundy and Biedenbender 1996) of the $25 \%$ - and $50 \%$-seed subpopulations were estimated for each seedlot for every hour as a function of average soil temperature for that hour using the nonlinear equations derived with Tablecurve ${ }^{\circledR} 2 \mathrm{D}$. Germination can be estimated to occur when the summation of hourly PTG estimates subsequent to planting reaches a value of 1 (Roundy and Biedenbender 1996). Thermal accumulation toward germination is expected to occur only when sufficient water is available for seed hydration. We separately calculated thermal progress toward germination during periods when estimates of water availability were above the following water potential thresholds: $-0.5,-1$, and $-1.5 \mathrm{MPa}$. In addition, we used 2 indices for characterizing potential cheatgrass germination. The first and most conservative method was to calculate the number of discrete, effective wet periods (EWP) within which germination progress was sufficient to achieve either $25 \%$ or $50 \%$ germination (number of wet periods where PTG $\geq 1$ ). The second method was to calculate PTG across all wet periods within a season, which we refer to as seasonal progress toward germination (SPTG). For modeling purposes, the first method assumed that cheatgrass seeds returned to their original germination potential if they dried out (soil at 1-3 cm reached a specified water potential threshold) before achieving radicle growth. The second method assumed that the cheatgrass seeds retained their thermal accumulation and progress toward germination during intermittent wet and dry periods. If SPTG $\geq 1$, then potential $25 \%$ or $50 \%$ germination is predicted for that treatment.
Average hourly soil temperatures from thermocouples buried in 2 treatment replicates were used to calculate PTG for each seedlot for every wet period and for each season (SPTG) for the three water potential threshold values $(-0.5,-1$, or, -1.5 $\mathrm{MPa}$ ) using the mean water potential estimate calculated from gypsum blocks buried in 3 treatment replicates. The number of EWP and the SPTG were analyzed in a mixed model (Littell et al. 1996), with site considered random, and cheatgrass seedlot, year, herbicide, and burn treatments considered fixed factors. The Tukey-Kramer method $(P<0.05)$ was used to determine significant differences among means for fixed factors (SAS Institute Inc. 1987). Best unbiased linear prediction equations (BLUPS) were used to estimate the potential number of EWP and SPTG values for sites and site by year (site-year) combinations (Littell et al. 1996). These analyses were conducted separately for 3 seasons: fall (September through November), winter (December through February), and spring (March through June), and for each water potential threshold. Consequently, 36 separate analyses were conducted: 3 water potential thresholds $\times 3$ seasons $\times 2$ germination responses (days to $25 \%$ and $50 \%$ germination) $\times 2$ thermal accumulation methods (number of EWP and values of SPTG).

We used discriminate analysis (SAS Institute Inc. 1987) to classify and predict germination success or failure as estimated by the number of EWP and SPTG as a function of meteorological variables for each combination of site, year, and season. Independent variables included average air temperature, total degree-days (sum of daily air temperatures above $0^{\circ} \mathrm{C}$ ), total precipitation, and days of precipitation. Discriminate analysis was used to predict success or failure across all seasons, as well as within the fall season.

\section{RESULTS}

\section{Effects of Estimation Parameters}

Both the number of EWP and SPTG values decreased with lessnegative water potential thresholds (Fig. 1, Table 1). The differences in germination indices were generally greater between the -0.5 and $-1 \mathrm{MPa}$ thresholds than between the -1 and $-1.5 \mathrm{MPa}$ thresholds (Fig. 1). The number of EWP estimated in spring averaged greater with the $-1 \mathrm{MPa}$ threshold than for the $-1.5 \mathrm{MPa}$ threshold because the latter resulted in fewer, but longer wet periods. For fall, the number of EWP was lowest when using a water potential threshold of $-0.5 \mathrm{MPa}$. SPTG was lowest in winter when using a water potential threshold of $-0.5 \mathrm{MPa}$ (Table 1, Fig. 1). Number of site years with successful predicted germination in fall and spring were more similar when using water potential thresholds of -1 and -1.5 , than $-0.5 \mathrm{MPa}$. Germination potential predictions based on EWP were similar for $25 \%$ and $50 \%$ germination in winter and in spring; but for fall, fewer successful site-years were predicted for $50 \%$ than $25 \%$ germination (Table 1). SPTG was less for the $50 \%$ subpopulation in fall and winter. SPTG estimates were similar for both subpopulations in the spring (Table 1). EWP estimates of germination potential were more conservative than those derived from SPTG (Fig. 1 and Table 1). These indices agreed in their predictions of potential germination success in the spring, but less so for fall, and least for winter. Winter 

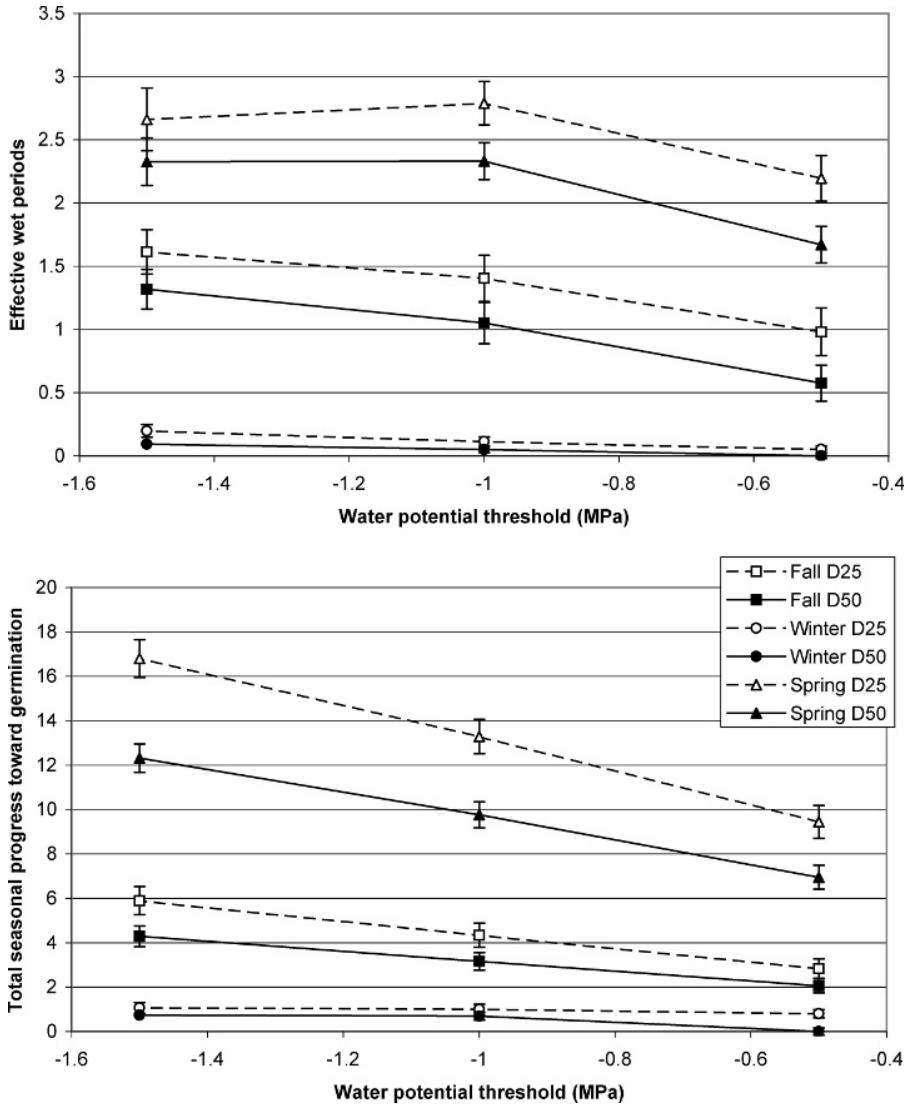

Figure 1. Seasonal number of effective wet periods (EWP) where thermal accumulation was sufficient for $25 \%$ (D25) and $50 \%$ (D50) germination of cheatgrass and total seasonal intermittent wet progress toward $25 \%$ and $50 \%$ germination (SPTG) for different water potential thresholds in big sagebrush seedbeds. Potential germination is predicted when EWP or SPTG $\geq 1$. Data are averaged across all years, sites, and disturbance treatments.

germination was predicted for about half of the site-years based on SPTG. There were no EWP in winter, and therefore no potential germination predicted for winter, based on the more conservative index.

\section{Effects of Seedlot, Season, and Site}

Seedlots. The number of EWP and SPTG values varied significantly $(P<0.001)$ among cheatgrass seedlots for both $25 \%$ and $50 \%$ subpopulations and for all seasons and all water potential thresholds. Seedlot germination rate responses to constant temperatures in incubators were most similar at suboptimal temperatures for the inverse of days to $25 \%$ germination and varied most at supraoptimal temperatures (Fig. 2). Although the germination indices varied significantly $(P<0.0001)$ among seedlots and the seedlot by year interaction was significant for SPTG $(P<0.05)$, most seedlots were similar in predicted potential germination for a season or year. For example, using the EWP index and a water potential threshold of $-1 \mathrm{MPa}$, germination failure was predicted for all seedlots in fall 2001, but all seedlots were predicted to germinate in fall 2002, 2003, and 2004. Similarly using the EWP index, all seedlots were predicted to successfully germinate every spring, and none were predicted to germinate in the winter. Using the SPTG index, all seedlots were predicted to germinate in fall and spring, but only 7 of 18 seedlots were predicted to germinate at the $25 \%$ level and only 2 seedlots at the $50 \%$ level in winter.

Season. Season had the strongest treatment effect in this study. The number of EWP and SPTG values was highest in spring, and lowest in winter (Fig. 1). Potential germination was predicted for almost all sites and years in spring using either germination index (Table 1). Winter germination was only predicted based on SPTG, and then only for about one-half of the 36 total site-years, depending on the water potential threshold. Potential germination was predicted for the majority of site-years in fall (Table 1), but predictions were sensitive to water potential thresholds and varied with the subpopulation.

Site. Site effects on potential germination varied with season (Fig. 3). In fall, lower-elevation big sagebrush sites had higher germination potential than upper-elevation sites. Using the EWP index, the Nevada crested wheatgrass site had the fewest years in which cheatgrass germination was predicted in the fall (Table 1). In spring, all sites had high germination potential for both germination indices. The crested wheatgrass and lower elevation big sagebrush sites had a greater number of EWP than the upper elevation sagebrush sites in spring. Nevada sites had increasing SPTG with increasing elevation in spring (Fig. 3). The EWP index predicted no potential germination on any sites in winter. SPGT was also low for winter, but generally predicted successful germination on more site-years for the lower elevation than upper elevation sites (Table 1). An exception to this was the Utah squirreltail site, which had limited SPTG values for winter germination. Winter SPTG values predicted no germination for the middle- and upperelevation sites in Nevada, but predicted germination on 1 to 4 site-years for similar sites in Utah, depending on the water potential threshold and germination percentage.

\section{Effects of Year and Disturbance}

EWP and SPTG indices varied significantly $(P<0.0001)$ by year for all seasons, water potential thresholds, and seed subpopulations. The EWP index predicted fall germination for all years except 2001; no winter germination; and germination every spring across all sites and disturbance treatments, using a water potential threshold of $-1 \mathrm{MPa}$ (Table 1). For these same treatments and water potential threshold, SPTG predicted germination every fall and spring, but for only 2 winter seasons.

Herbicide and burn treatment main effects were also significant $(P<0.05)$ for EWP and SPTG indices for some water potential thresholds and seed subpopulations. The year by herbicide (live vs. dead) by burn interaction was significant $(P<0.05)$ for both indices for most combinations of water potential threshold and seed subpopulation. Annual weather (year) had a much greater effect on the germination indices than did disturbance for all seasons (Fig. 4). For example, fall EWP between 2001 and 2002 differed significantly $(P<0.05)$ by about 1.5 for each herbicide-burn treatment combination, but within these years, differences in EWP among herbicideburn treatment combinations were $<0.5$ (Fig. 4). Annual precipitation varied among years and among sites within years 
Table 1. Number of years out of 4 for 9 sites and number of site-years out of 36 for 9 sites $\times 4$ years that sufficient degree-days were accumulated for 25\% (D25) and 50\% (D50) germination of cheatgrass seeds. Numbers calculated by continuous wet period (effective wet period [EWP]) require that sufficient degree-days for germination had to accumulate within at least one continuously wet period for a season. Numbers calculated for all wet periods (seasonal progress toward germination [SPTG]) assume that degree-days for germination were accumulated across all wet periods within a season. Water potential thresholds indicate different seedbed water potentials above which seed thermal accumulation was calculated.

\begin{tabular}{|c|c|c|c|c|c|c|c|c|c|c|c|c|}
\hline \multirow[b]{2}{*}{ Season } & \multirow{2}{*}{$\begin{array}{l}\text { Germination } \\
\text { fraction }\end{array}$} & \multirow{2}{*}{$\begin{array}{l}\text { Water potential } \\
\text { threshold (MPa) }\end{array}$} & \multicolumn{4}{|c|}{ Nevada } & \multirow[b]{2}{*}{ Squirreltail } & \multicolumn{4}{|c|}{ Utah } & \multirow[b]{2}{*}{ All Sites } \\
\hline & & & Crested & Low & Middle & Upper & & Crested & Low & Middle & Upper & \\
\hline \multirow[t]{6}{*}{ Fall } & D25 & -0.5 & 0 & 3 & 1 & 1 & 0 & 3 & 3 & 3 & 1 & 15 \\
\hline & & -1 & 1 & 3 & 3 & 2 & 3 & 3 & 4 & 3 & 3 & 25 \\
\hline & & -1.5 & 3 & 3 & 3 & 3 & 3 & 3 & 4 & 3 & 3 & 28 \\
\hline & D50 & -0.5 & 0 & 2 & 0 & 0 & 0 & 3 & 2 & 3 & 0 & 10 \\
\hline & & -1 & 0 & 3 & 1 & 1 & 3 & 3 & 3 & 3 & 2 & 19 \\
\hline & & -1.5 & 1 & 3 & 3 & 3 & 3 & 3 & 4 & 3 & 3 & 26 \\
\hline \multirow[t]{6}{*}{ Winter } & D25 & -0.5 & 0 & 0 & 0 & 0 & 0 & 0 & 0 & 0 & 0 & 0 \\
\hline & & -1 & 0 & 0 & 0 & 0 & 0 & 0 & 0 & 0 & 0 & 0 \\
\hline & & -1.5 & 0 & 0 & 0 & 0 & 0 & 0 & 0 & 0 & 0 & 0 \\
\hline & D50 & -0.5 & 0 & 0 & 0 & 0 & 0 & 0 & 0 & 0 & 0 & 0 \\
\hline & & -1 & 0 & 0 & 0 & 0 & 0 & 0 & 0 & 0 & 0 & 0 \\
\hline & & -1.5 & 0 & 0 & 0 & 0 & 0 & 0 & 0 & 0 & 0 & 0 \\
\hline \multirow[t]{6}{*}{ Spring } & D25 & -0.5 & 4 & 4 & 4 & 4 & 0 & 4 & 4 & 4 & 4 & 32 \\
\hline & & -1 & 4 & 4 & 4 & 4 & 4 & 4 & 4 & 4 & 4 & 36 \\
\hline & & -1.5 & 4 & 4 & 4 & 4 & 4 & 4 & 4 & 4 & 3 & 35 \\
\hline & D50 & -0.5 & 1 & 4 & 4 & 4 & 4 & 4 & 4 & 4 & 3 & 32 \\
\hline & & -1 & 4 & 4 & 4 & 4 & 4 & 4 & 4 & 4 & 4 & 36 \\
\hline & & -1.5 & 4 & 4 & 4 & 4 & 4 & 4 & 4 & 4 & 3 & 35 \\
\hline \multirow[t]{6}{*}{ Fall } & $\mathrm{D} 25$ & -0.5 & 4 & 3 & 4 & 3 & 3 & 4 & 4 & 4 & 3 & 32 \\
\hline & & -1 & 4 & 3 & 4 & 3 & 3 & 4 & 4 & 4 & 4 & 33 \\
\hline & & -1.5 & 4 & 3 & 4 & 3 & 4 & 4 & 4 & 4 & 4 & 34 \\
\hline & D50 & -0.5 & 3 & 4 & 3 & 3 & 3 & 4 & 4 & 4 & 3 & 31 \\
\hline & & -1 & 2 & 4 & 3 & 3 & 4 & 4 & 4 & 4 & 3 & 31 \\
\hline & & -1.5 & 3 & 4 & 3 & 3 & 4 & 4 & 4 & 4 & 4 & 33 \\
\hline \multirow[t]{6}{*}{ Winter } & D25 & -0.5 & 2 & 3 & 0 & 0 & 0 & 2 & 4 & 3 & 1 & 15 \\
\hline & & -1 & 2 & 3 & 0 & 0 & 1 & 2 & 4 & 4 & 2 & 18 \\
\hline & & -1.5 & 2 & 3 & 0 & 0 & 2 & 2 & 4 & 4 & 2 & 19 \\
\hline & D50 & -0.5 & 0 & 0 & 0 & 0 & 0 & 0 & 0 & 0 & 0 & 0 \\
\hline & & -1 & 2 & 2 & 0 & 0 & 0 & 2 & 4 & 2 & 1 & 13 \\
\hline & & -1.5 & 2 & 2 & 0 & 0 & 0 & 2 & 4 & 2 & 2 & 14 \\
\hline \multirow[t]{6}{*}{ Spring } & $\mathrm{D} 25$ & -0.5 & 4 & 4 & 4 & 4 & 4 & 4 & 4 & 4 & 4 & 36 \\
\hline & & -1 & 4 & 4 & 4 & 4 & 4 & 4 & 4 & 4 & 4 & 36 \\
\hline & & -1.5 & 4 & 4 & 4 & 4 & 4 & 4 & 4 & 4 & 4 & 36 \\
\hline & D50 & -0.5 & 4 & 4 & 4 & 4 & 4 & 4 & 4 & 4 & 4 & 36 \\
\hline & & -1 & 4 & 4 & 4 & 4 & 4 & 4 & 4 & 4 & 4 & 36 \\
\hline & & -1.5 & 4 & 4 & 4 & 4 & 4 & 4 & 4 & 4 & 4 & 36 \\
\hline
\end{tabular}

for each season (Fig. 5). Fall 2001 precipitation was especially low, and for most sites and years, precipitation was below the PRISM (2006) average except for fall 2004 and spring 2005. Herbicide treatment to kill native herbaceous understory had little effect on predicted germination performance (Fig. 4). Although burning increased thermal accumulation during wet periods in some cases, as evidenced by significantly higher $(P<0.05)$ EWP and SPTG for some years and herbicide treatments (Fig. 4), it did not affect the total number of years or wet periods that resulted in potential germination for the 2 seed subpopulations.

\section{Using Meteorological Variables to Predict Potential Germination}

Discriminant analysis of potential germination response as a function of season, mean daily air temperature, total degreedays, total days of precipitation, and total precipitation for the season correctly classified cases of no germination $79 \%$ of the time, and cases of potential germination $95 \%$ of the time (Table 2). The results in Table 2 are for the $25 \%$ seed subpopulation, the EWP index, and a water potential threshold of $-1 \mathrm{MPa}$; however, classifications were similar for both subpopulations and for any water potential threshold and 

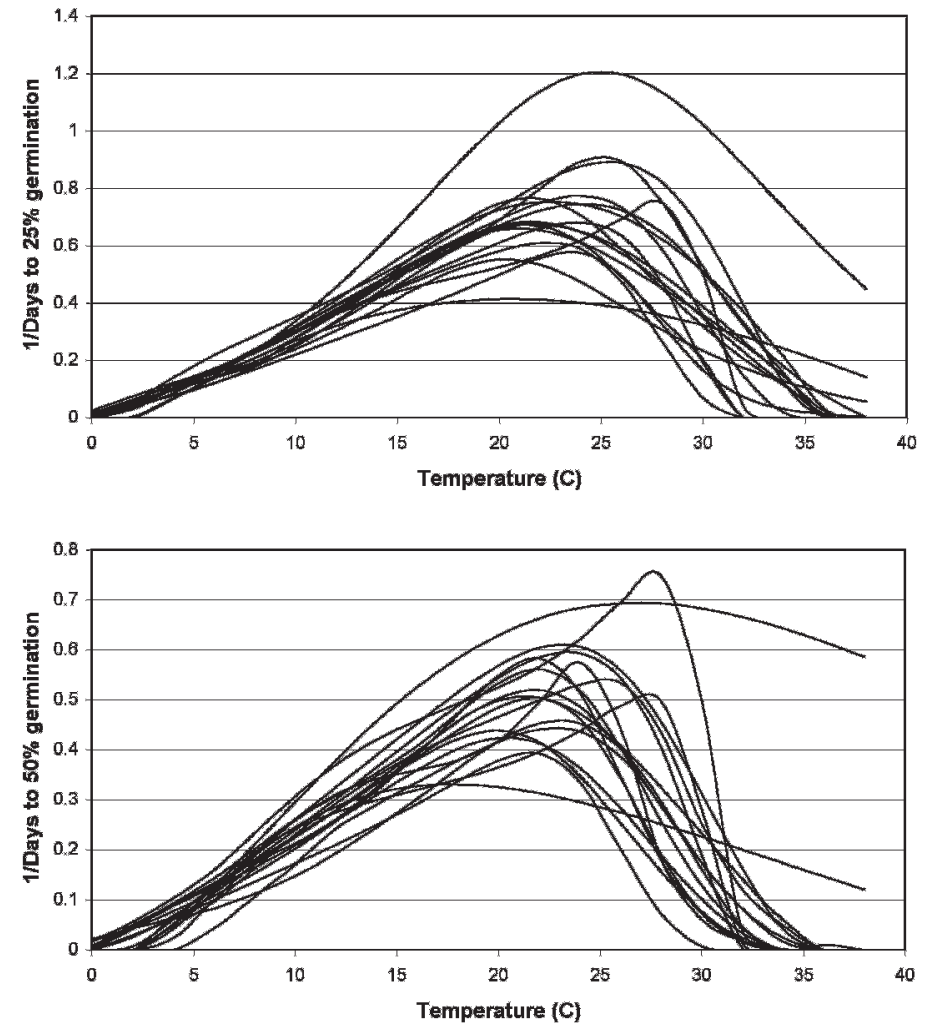

Figure 2. Curvilinear germination rate responses of 18 cheatgrass seedlots to constant incubation temperatures as modeled by Tablecurve ${ }^{\circledR} 2 \mathrm{D}$. $R^{2}$ values ranged from to 0.74 to 0.99 , with 23 of the 36 curves having an $R^{2}>0.90$.

germination index. Mean daily air temperature and degreedays were the best predictors of germination potential across all seasons, as indicated by their simple $r^{2}$ values (Table 2 ). Discriminant analysis was also used to predict specific germination potential for the fall season, because the fall had relatively high variation in potential germination among sites and years relative to the winter (low germination) and spring (high germination). Based on the higher $r^{2}$ for degree-days than air temperature for seasonal predictions (Table 2), and the recognition that precipitation would be a limiting factor for wet thermal accumulation in fall, we only used degree-days and total precipitation to predict successful fall germination. Using these 2 variables, the discriminant functions correctly classified $90 \%$ (9) of the 10 site-years having no potential germination and $76 \%$ (19) of the 25 site-years having potential germination for the fall season (Table 2).

\section{DISCUSSION}

We suggest that a reasonable comparison of potential cheatgrass germination as a function of season, year, and disturbance can be obtained from our data using thermal accumulation toward $25 \%$ germination above a water potential threshold of $-1 \mathrm{MPa}$. Cheatgrass seeds have been shown to germinate at water potentials as low as $-1.5 \mathrm{MPa}$ (Pyke and Novak 1994; Christensen et al. 1996). Taylor et al. (2007) found that the base water potential for the fastest $50 \%$ seed
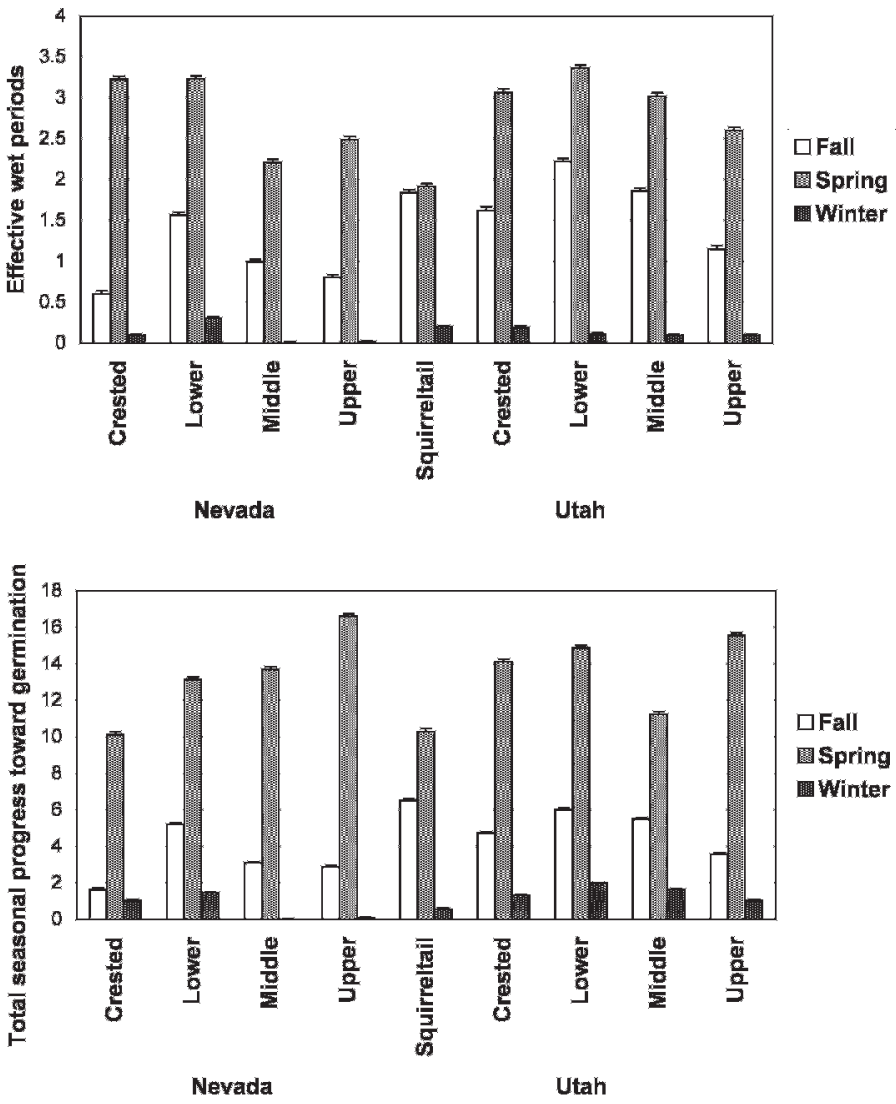

Figure 3. Number of effective wet periods (EWP) fulfilling thermal progress toward $25 \%$ germination (top) and total seasonal intermittent wet progress (SPTG) toward $25 \%$ of cheatgrass germination (bottom, potential germination when total progress $\geq 1$ ) for 9 big sagebrush sites and over a 4-year period in Nevada and Utah. Data are averaged across all years and disturbance treatments. Wet means the seedbed was $\geq-1 \mathrm{MPa}$.

fraction for 3 cheatgrass seedlots in Utah ranged from -0.76 to $-1.06 \mathrm{MPa}$. Hardegree et al. (2003) found that for a long-term field simulation, about $80 \%$ of the hydrothermal accumulation for the $10 \%$ seed subpopulation of two cheatgrass seedlots occurred at water potentials $>-1 \mathrm{MPa}$. Use of the $25 \%$ rather than the $50 \%$ subpopulation for modeling is reasonable for a species such as cheatgrass which is a prolific seed producer and may have $>15000$ viable seeds $\cdot \mathrm{m}^{-2}$ in degraded big sagebrush communities (Young and Evans 1985; Meyer et al. 2007). Although a hot fire can greatly reduce the cheatgrass seedbank, prolific seed production of the seedlings that do establish can be expected to restock the seedbank within a few years (Young and Evans 1978).

A rather robust way of comparing relative effects of different factors on potential germination is to compare the standard deviations of the potential germination indices for each statistically significant factor across all other factors. Because the means of these factors across all other factors are the same, a larger standard deviation would indicate greater variation overall, and therefore a greater relative effect of that factor on the potential germination index variable. The maximumminimum value for a factor also gauges relative effect. Using a $-1 \mathrm{MPa}$ threshold water potential and a $25 \%$ germination 

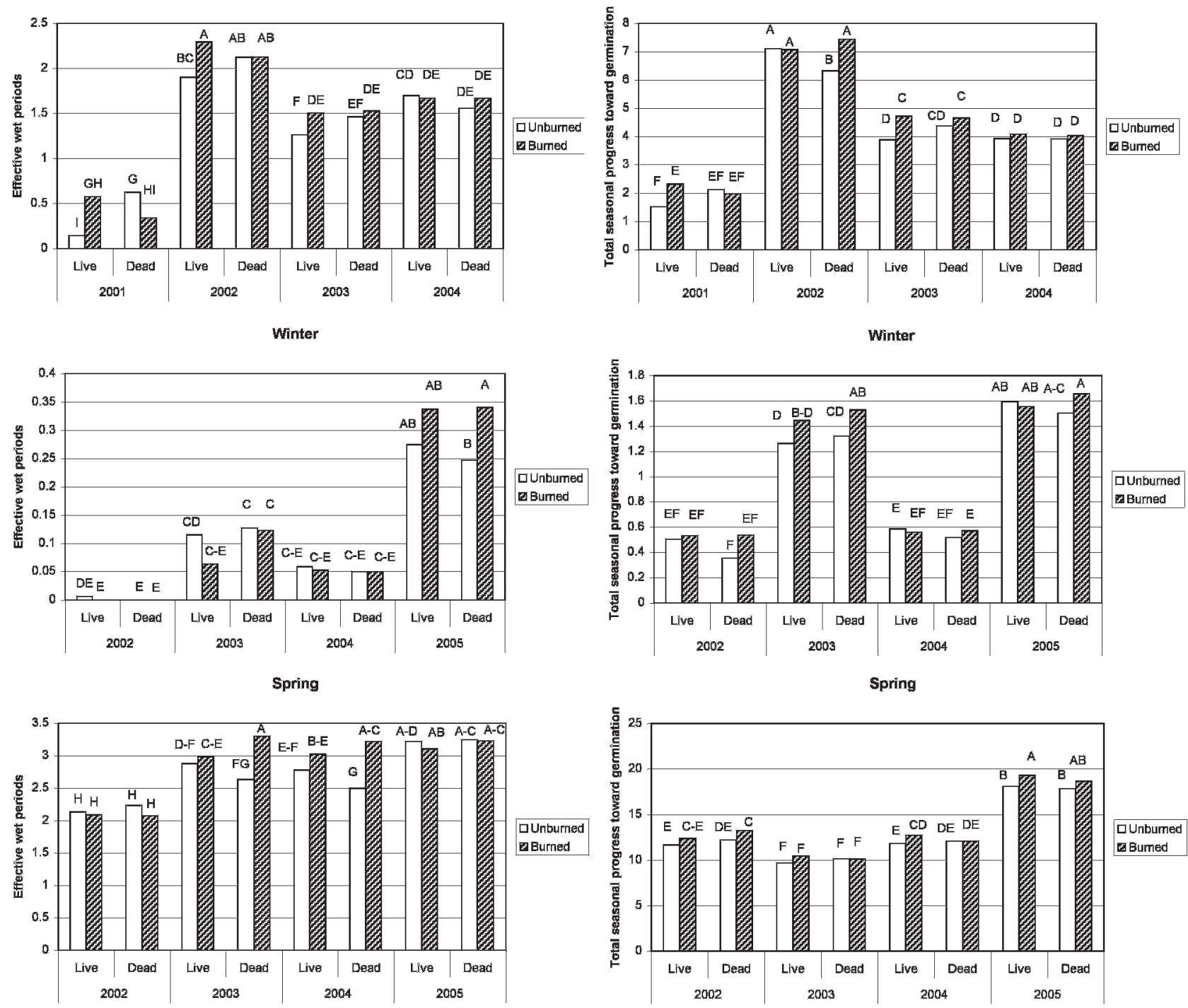

Figure 4. Number of effective wet periods fulfilling thermal progress toward $25 \%$ germination (left) and total seasonal intermittent wet progress toward $25 \%$ of cheatgrass germination (right) for seasons, years, and vegetation disturbances in Nevada and Utah. Data are averaged across all big sagebrush sites. Live = herbaceous understory perennials left intact. Dead = herbaceous perennials removed with an herbicide in 2001. Burned $=$ burned in 2001. Different letters above bars indicate significant differences for those values $(P<0.05)$.

percentage, the relative effect on EWP was greatest for season, followed by year (annual weather), site, and was minimal for herbicide and fire disturbance treatments (Fig. 6). For these same parameters, the relative effect on SPTG was also greatest for season, about equal for year and site, and also minor for the disturbance factors.

Why did fire and vegetation removal by herbicides not have a greater effect on wet thermal accumulation for germination? Fire can increase soil temperatures (Whisenant et al. 1984; Sumrall et al. 1991; Chambers and Linnerooth 2001), but neither fire nor understory vegetation removal increased the time of surface soil water availability in the first 2 years of this study (Whittaker 2006). Reduction of understory vegetation by disturbance would be expected to reduce transpirational soil water loss and increase time of subsurface soil water availability. It should have less effect on surface soil water availability, which is more responsive to surface atmospheric conditions. In this study, big sagebrush plants within the plots were removed by burning, but roots from surrounding live sagebrush plants might have influenced soil water potential in the plots (Chambers et al. 2007). Greater perennial herbaceous growth after burning of live (nonsprayed) plots also might have increased transpirational water loss on burned plots. Chambers and Linneroth (2001) found that surface soils of larger burned plots dried out faster than those on unburned plots, probably because snow blew off of them and because they had higher soil temperatures compared to unburned plots. In our study, apparently surface soil water availability as influenced mainly by precipitation and soil water evaporation had a greater effect on wet thermal accumulation for germination than did vegetation disturbance.

Our data show that seasonal soil water availability and soil temperatures were adequate for high-potential cheatgrass germination on both undisturbed and disturbed plots, especially in spring. Taylor et al. (2007) found that gypsum blocks dried out 4-6 days after the seed zone dried in a sandy loam 
Fall: September-November

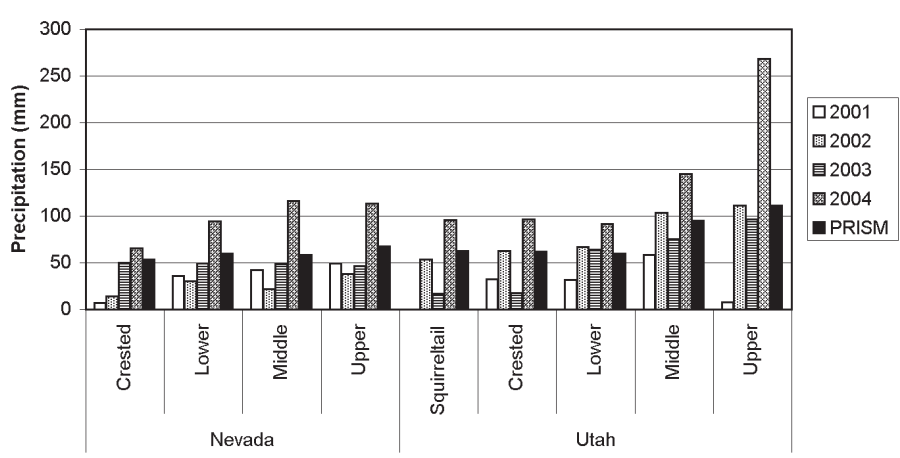

Winter: December-February

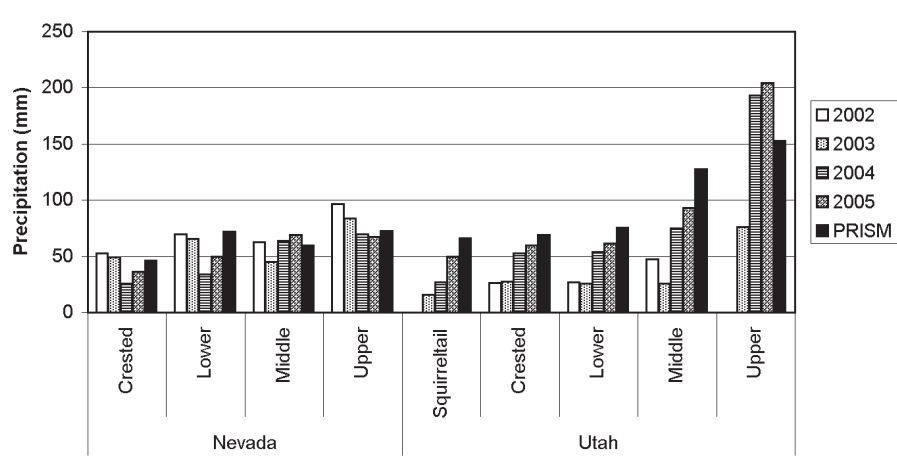

Spring: March-June

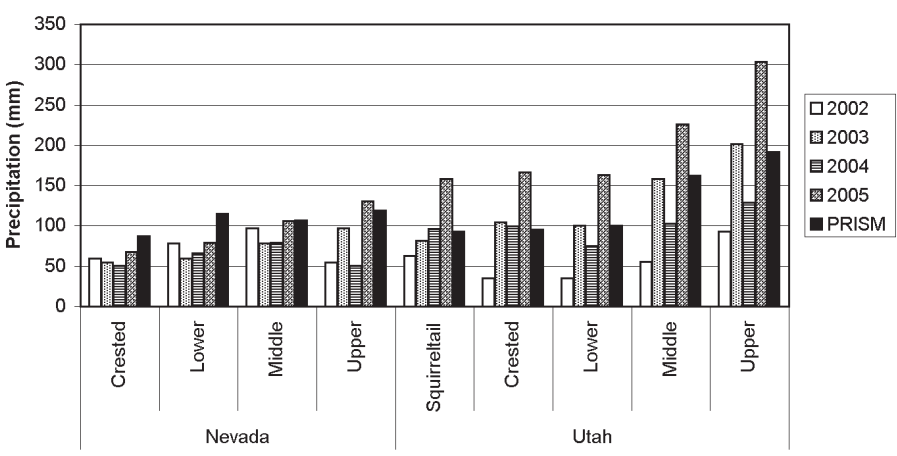

Figure 5. Seasonal precipitation measured on site for 4 years and site average precipitation estimated by PRISM (2006) for 9 big sagebrush sites in Nevada and Utah.

soil in a growth chamber programmed to simulate spring soil temperatures for Provo, Utah. Such sensor delay could cause an overestimation of wet thermal time and potential germination. Reducing the time of water availability by up to 6 days in thermal accumulation calculations for our data did not reduce predicted potential cheatgrass germination in spring. These reductions did lower predicted fall germination to 1 in 4 years, but such water availability reductions should probably not apply to fall thermal accumulation. We have found that in fall, gypsum blocks might not wet up as fast as the seed zone with the onset of fall rains, thereby potentially underestimating wet thermal time under some conditions.

We conclude that disturbance of big sagebrush plant communities in the Great Basin is generally not necessary for cheatgrass germination because 1) disturbance has little effect
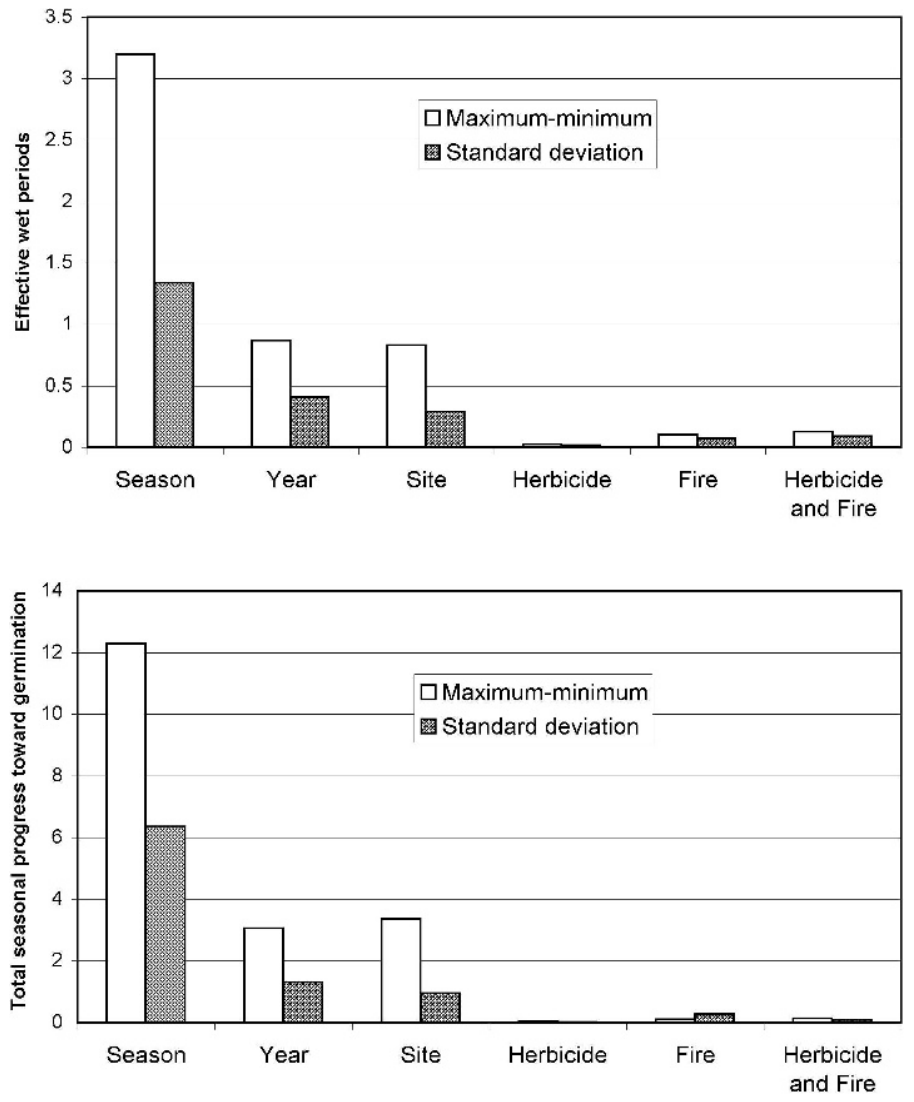

Figure 6. Maximum-minimum values and standard deviations of factors affecting number of continuously effective wet periods (top) and intermittent wet periods (bottom) fulfilling thermal requirements for $25 \%$ germination of cheatgrass where wet $\geq-1 \mathrm{MPa}$. Herbicide disturbance removed the perennial herbaceous understory.

on wet thermal accumulation, and 2) concurrent soil moisture and temperature conditions are generally adequate for germination without disturbance. Because we conducted our study on 9 sites during 3 years of below-average and 1 year of aboveaverage precipitation, these conclusions should be fairly robust.

Our discriminant analysis results indicate the relative importance of temperature in predicting seasonal germination (Table 2). Total degree-days, based on daily air temperatures, was the strongest predictor of seasonal germination potential. An average of $658 \pm 21$ degree-days was associated with potential germination compared to $220 \pm 49$ for season-siteyears that lacked potential germination. Degree-days from daily air temperatures averaged $746 \pm 30$ for fall, $71.3 \pm 6.9$ for winter, and $1146 \pm 40$ for spring. Because no thermal accumulation occurs when seeds are dry, germination is limited by lack of precipitation during dry falls and then limited by cold temperatures when precipitation comes in late November. Germination is also limited during wet winters until seedbeds warm up in spring (Mack and Pyke 1983; Hardegree et al. 2003).

Faster germination results in higher potential germination in fall because wet thermal accumulation is dependent on the onset of fall rains before temperatures become limiting. Faster germination also results in higher potential germination in winter when cool temperatures limit thermal accumulation. Potential germination of the $25 \%$ and $50 \%$ subpopulations 
Table 2. Potential cheatgrass germination across all seasons and for fall only and the means \pm standard errors and $r^{2}$ values of meteorological variables used to predict germination using discriminant analyses. Potential germination was originally estimated from thermal accumulation to $25 \%$ germination using a water potential threshold of $-1 \mathrm{MPa}$.

\begin{tabular}{|c|c|c|c|c|c|c|c|}
\hline & $\begin{array}{l}\text { Mean daily } \\
\text { (C) }\end{array}$ & $\begin{array}{l}\text { Total degree } \\
\text { days }\end{array}$ & $\begin{array}{l}\text { Days of } \\
\text { precipitation }\end{array}$ & $\begin{array}{l}\text { Total precipitation } \\
(\mathrm{mm})\end{array}$ & $\begin{array}{l}\text { Observations } \\
\text { correctly } \\
\text { classified (\%) }\end{array}$ & $n$ & $\begin{array}{l}\text { Observations } \\
\text { correctly } \\
\text { classified (no.) }\end{array}$ \\
\hline \multicolumn{8}{|l|}{ All seasons } \\
\hline No germination & $0.92 \pm 1.2$ & $220 \pm 49$ & $16.5 \pm 1.5$ & $34.2 \pm 4.5$ & 79 & 43 & 34 \\
\hline Germination & $8.7 \pm 0.4$ & $658 \pm 21$ & $11.4 \pm 0.9$ & $80.2 \pm 7.0$ & 95 & 59 & 56 \\
\hline$r^{2}$ & 0.49 & 0.81 & 0.09 & 0.25 & & & \\
\hline \multicolumn{8}{|l|}{ Fall } \\
\hline No germination & & $841 \pm 44$ & & $37.7 \pm 5.7$ & 90 & 10 & 9 \\
\hline Germination & & $708 \pm 36$ & & $78.6 \pm 10.5$ & 76 & 25 & 19 \\
\hline$r^{2}$ & & 0.12 & & 0.15 & & & \\
\hline
\end{tabular}

was more similar in spring when both available soil moisture and warm temperatures are less limiting than in winter or fall when the $25 \%$ subpopulation had higher potential germination than the $50 \%$ subpopulation (Table 1). More consistent accumulation of thermal time for spring than fall germination in our study parallels observations and analyses of others. Although cheatgrass is reported normally to germinate in fall (Carpenter and Murray 2005), Martens et al. (1994) considered that cheatgrass only germinates in the fall in the western Great Basin once in every 5 years. Hardegree et al. (2003) modeled seedbed microclimates in southern Idaho and also found predicted germination rates of cheatgrass to be higher in spring than fall. Using soil-water and gap-dynamics models, Bradford and Lauenroth (2006) concluded that climate was the major determinant of cheatgrass invasion susceptibility, and that sagebrush steppe areas had higher establishment probabilities in spring than fall. Our results indicate that spring germination is more dependable than fall germination in the central and eastern Great Basin.

In fall, seedbeds are already warm and germination is dependent on precipitation for hydration before freezing and near-freezing temperatures limit thermal accumulation. Degree-days for the fall discriminant analysis were inversely correlated with potential germination (841 degree-days for no germination and 708 for potential germination; Table 2). Higher temperatures and greater degree-days are associated with fewer storms, less rainfall, higher evaporative demand, and less time of available water in fall. The usual midwinter precipitation of the Great Basin climate is generally out of phase with temperatures conducive to growth (Martens et al. 1994). However, precipitation in the central and eastern Great Basin can actually peak in October or May when temperatures are warm enough for germination and growth. These peaks are due to high altitude, low pressure systems, referred to as lows aloft (Richardson et al. 1989). Lows aloft are erratic in movement and often produce heavy precipitation that is less dependent on elevation and orographic lifting than Pacific frontal storms, which are most frequent in winter and early spring. Lows aloft in October should result in fall germination of cheatgrass.

Cheatgrass germination rarely occurs in summer when seedlings are susceptible to subsequent drought, or in late fall when very young seedlings are susceptible to freezing injury.
Cheatgrass seed populations have a dry afterripening requirement to prevent germination between seed shatter in early summer and fall rains (Beckstead et al. 1996; Bauer et al. 1998). Failure to germinate in fall because of lack of water for seeds present in the litter (Young et al. 1969), followed by induction of secondary dormancy during the winter (Young and Evans 1975; Kelrick 1991) might allow some seeds to remain dormant in the seedbank until the following fall and environmental conditions allow for seedling establishment (Pyke and Novak 1994; Meyer et al. 2007). Seeds acquiring secondary dormancy are not available for spring germination, but seeds that do not germinate or acquire secondary dormancy in the fall or winter have high potential for spring germination (Mack and Pyke 1983; Meyer et al. 2007). These nondormant seeds must account for the frequently observed emergence of spring seedling cohorts.

Our most conservative predictions of EWP germination with a $-0.5 \mathrm{MPa}$ water potential threshold were also high in the spring. The less conservative estimate of cheatgrass germination using the SPTG index might be more relevant depending upon the physiological response of cheatgrass to heat accumulation during periods of wetting, drying, and rewetting. Seeds of some species which have been dehydrated before initiating radical growth can tolerate desiccation and even retain a degree of the germination progress made during initial hydration (Allen et al. 1993; Bradford 1995; Hardegree and Van Vactor 2000). Previous studies of several grass species indicate that the ability of a seed to retain progress toward germination after drying is a function of the timing and severity of the dehydration episode (Allen et al. 1993; Debaene-Gill et al. 1994). If cheatgrass does retain enhanced germinability during intermittent drying episodes, then it would exhibit the higher germination potential that was estimated using the SPTG index in this study.

\section{MANAGEMENT IMPLICATIONS}

Cheatgrass can fail to accumulate sufficient wet thermal time to germinate on drier sites and years than were measured in this study. However, this study was conducted mainly during years of below-average precipitation indicating that wet thermal accumulation for cheatgrass germination is generally adequate with or without disturbance. These predictions and conclusions 
should be tested with field observations of cheatgrass germination. Our modeling results indicate that seed germination does not appear to limit cheatgrass invasion and dominance of big sagebrush communities in the Great Basin, but that cheatgrass is constrained more by seedling survival and reproductive output as affected by resource availability. Ecophysiological limitations on plant growth and seed production exist at higher elevations and on colder aspects (Chambers et al. 2007). Under favorable growing conditions competition from native herbaceous species reduces cheatgrass biomass and seed numbers (Chambers et al. 2007). This indicates that for climatic zones favorable for cheatgrass, invasion and dominance is best limited by maintaining these communities in good condition with relatively high density and cover of perennial herbaceous species.

\section{LITERATURE CITED}

Allen, P., S. D. B. White, and A. H. Markhart III. 1993. Germination of perennial ryegrass and annual bluegrass seeds subjected to hydration-dehydration cycles. Crop Science 33:1020-1025.

Bair, N. B., S. E. Meyer, and P. S. Allen. 2006. A hydrothermal after-ripening time model for seed dormancy loss in Bromus tectorum L. Seed Science Research 16:17-28.

Bauer, M., S. E. Meyer, and P. S. Allen. 1998. A simulation model to predict seed dormancy loss in the field for Bromus tectorum L. Journal of Experimental Botany 324:1235-1244.

Beckstead, J., and C. K. Augspurger. 2004. An experimental test of resistance to cheatgrass invasion: limiting resources at different life stages. Biological Invasions 6:417-432.

Beckstead, J., S. E. Meyer, and P. S. Allen. 1996. Bromus tectorum seed germination: between-population and between-year variation. Canadian Journal of Botany 74:875-882.

Biluings, W. D. 1990. Bromus tectorum, a biotic cause of impoverishment in the Great Basin. In: G. M. Woodell [ED.]. The earth in transition: Patterns and processes of biotic impoverishment. Cambridge, United Kingdom: Cambridge University Press. p. 301-322.

Booth, M. S., M. M. Caldwell, and J. M. StaRk. 2003. Overlapping resource use in three Great Basin species: implications for community invasibility and vegetation dynamics. Journal of Ecology 91:36-48.

Bradford, J. B., and W. K. Lauenroth. 2006. Controls over invasion of Bromus tectorum: the importance of climate, soil, disturbance and seed availability. Journal of Vegetation Science 17:693-704.

BradFoRd, K. J. 1995. Water relations in seed germination. In: J. Kigel and G. Galili [EDS.]. Seed development and germination. New York, NY: Marcel Dekker. p. 351-396.

Brooks, M. L., AND D. A. PYKE. 2001. Invasive plants and fire in the deserts of North America. In: K. E. M. Galley and T. P. Wilson [EDS.]. Proceedings of the Invasive Species Workshop: The role of fire in the control and spread of invasive species. Fire Conference 2000: The First National Congress on Fire Ecology, Prevention, and Management. Miscellaneous Publication No. 11. Tallahassee, FL: Tall Timbers Research Station. p. 1-14.

Campbell Scientific, Inc. 1983. Model 227 Delmhorst cylindrical soil moisture block instruction manual. Logan, UT: Campbell Scientific. 5 p.

Carpenter, A. T., and T. A. Murray. 2005. Element stewardship abstract for Bromus tectorum L. (Anisantha tectorum [L.] Nevski). Arlington, VA: The Nature Conservancy. $27 \mathrm{p}$.

Chambers, J. C., And A. R. Linneroth. 2001. Restoring riparian meadows currently dominated by Artemisia using alternative state concepts-the establishment component. Applied Vegetation Science 4:157-166.

Chambers, J. C., B. A. Roundy, R. R. Blank, S. E. Meyer, and A. Whittaker. 2007. What makes Great Basin sagebrush ecosystems invasible by Bromus tectorum? Ecological Monographs 77:117-145.
Christensen, M., S. E. Meyer, and P. S. Allen. 1996. A hydrothermal time model of seed after-ripening in Bromus tectorum L. Seed Science Research 6: 155-163.

D'Antonio, C. M., and P. M. Vitousek. 1992. Biological invasions by exotic grasses, the grass/fire cycle, and global change. Annual Review of Ecology and Systematics 23:63-87.

Davis, M. A., J. P. Grime, and K. Thompson. 2000. Fluctuating resources in plant communities: a general theory of invasibility. Journal of Ecology 88:528534.

Debaene-Gill, S. B., P. S. Allen, and D. B. White. 1994. Dehydration of germinating perennial ryegrass seeds can alter rate of subsequent radicle emergence. Journal of Experimental Botany 45:1301-1307.

Douglas, B. J., A. G. Thomas, and D. A. Derksen. 1990. Downy brome (Bromus tectorum) invasion into southwestern Saskatchewan. Canadian Journal of Plant Science 70:1143-1151.

Hardegree, S. P. 2006. Predicting germination response to temperature. I. Cardinal-temperature models and subpopulation-specific regression. Annals of Botany 97:1115-1125.

Hardegree, S. P., G. N. Flerchinger, and S. S. Van Vactor. 2003. Hydrothermal germination response and the development of probabilistic germination profiles. Ecological Modeling 167:305-322.

Hardegree, S. P., and S. S. Van Vactor. 2000. Germination and emergence of primed grass seeds under field and simulated field temperature regimes. Annals of Botany 85:379-390.

Humphrey, L. D., And E. W. Schupp. 2004. Competition as a barrier to establishment of a native perennial grass (Elymus elymoides) in alien annual grass (Bromus tectorum) communities. Journal of Arid Environments 58:405-422.

KeLRICK, M. I. 1991. Factors affecting seeds in a sagebrush ecosystem and implications for the dispersion of an annual plant species, cheatgrass (Bromus tectorum L.) [dissertation]. Logan, UT: Utah State University. 223 p.

Knapp, P. A. 1996. Cheatgass (Bromus tectorum) dominance in the Great Basin Desert. Global Environmental Change 6:37-52.

Korfmacher, J. L., J. C. Chambers, R. J. Tausch, B. Roundy, S. Meyer, and S. Kitchen. 2003. Technical Note: a technique for conducting small-plot burn treatments. Journal of Range Management 56:251-254.

Littell, R. C., G. A. Milliken, W. W. Stroup, and R. D. Wolfinger. 1996. SAS system for mixed models. Cary, NC: SAS Institute. $633 \mathrm{p}$.

Mack, R. N. 1986. Alien plant invasions into the Intermountain West: a case history. In: H. A. Mooney and J. Drake [EDS.]. Ecology of biological invasions in North America and Hawaii. New York, NY: Springer-Verlag. p. 192-213.

Mack, R. N., And D. A. PYke. 1983. The demography of Bromus tectorum: variation in time and space. Journal of Ecology 71:69-93.

Martens, E., D. Palmouist, and J. A. Young. 1994. Temperature profiles for germination of cheatgrass versus native perennial bunchgrasses. In: S. B. Monsen and S. G. Kitchen [CompILers]. Proceedings-Ecology and Management of Annual Rangelands; 18-22 May 1992. Ogden, UT: USDA Forest Service Intermountain Research Station, General Technical Report INTGTR-313. p. 238-243.

Meyer, S. E., P. S. Allen, and J. Beckstead. 1997. Seed germination regulation in Bromus tectorum L. (Poaceae) and its ecological significance. Oikos 78:475-485

Meyer, S. E., S. C. Garvin, and J. Beckstead. 2001. Factors mediating cheatgrass invasion of intact salt desert shrubland. In: E. D. McArthur and D. J. Fairbanks [CoMPILERS]. Proceedings-Shrubland Ecosystem Genetics and Biodiversity; 13-15 June 2000. Provo, UT: US Department of Agriculture, Forest Service, Rocky Mountain Research Station, RMRS-P-21. p. 224-232.

Meyer, S. E., D. Quinney, J. Weaver, and D. L. Nelson. 2007. Impact of the pathogen Pyrenophora semeniperda on Bromus tectorum seed bank dynamics in North American cold deserts. Weed Research 47:54-62.

PRISM. 2006. Parameter-elevation regression on independent slopes model. Available at: http//forest.moscowfls,wsu.edu/engr/climatesw.html. Accessed December 2006

PykE, D. A., AND S. J. Novak. 1994. Cheatgrass demography-establishment attributes, recruitment, ecotypes, and genetic variablility. In: S. B. Monsen and S. G. Kitchen [ComplLERS]. Proceedings-Ecology and Management of Annual 
Rangelands; 18-22 May 1992. Ogden, UT: USDA Forest Service Intermountain Research Station, General Technical Report INT-GTR-313. p. 12-21.

RICE, K. J., AND R. N. Mack. 1991. Ecological genetics of Bromus tectorum: intraspecific variation in phenotypic plasticity. Oecologia 88:84-90.

Richardson, E. A., G. L. Ashcroft, and J. K. Westbrook. 1989. Precipitation. In: K. L. Johnson [ED.]. Rangeland resources of Utah. Logan, UT: Utah State University. p. 12-14.

Roundy, B. A., AND S. H. BIEDEnBEnder. 1996. Germination of warm-season grasses under constant and dynamic temperatures. Journal Range Management 49:425-431.

SAS INSTITUTE, INC. 1987. SAS/STAT ${ }^{\text {TM }}$ Guide for personal computers, Version 6 ed. Cary, NC: SAS Institute Inc. 1028 p.

Stevens, A. R. 1997. Squirreltail (Elymus elymoides) establishment and competition with cheatgrass (Bromus tectorum) [dissertation]. Provo, UT: Brigham Young University. 57 p.

Sumrall, L. B., B. A. Roundy, J. R. Cox, And V. K. Winkel. 1991. Influence of canopy removal by burning or clipping on emergence of Eragrostis lehmanniana seedlings. International Journal of Wildland Fire 1:35-40.

Taylor, J. R., B. A. Roundy, P. S. Allen, and S. E. Meyer. 2004. Predicting seedling emergence using soil moisture and temperature sensors. In: A. L. Hild, N. L. Shaw, S. E. Meyer, D. T. Booth, and E. D. McArthur [complLers]. Seed and soil dynamics in shrubland ecosystems. Proceedings RMRS-P-31. Fort Collins, C0: USDA Forest Service Rocky Mountain Research Station. p. 140-145.

Taylor, J. R., B. A. Roundy, P. S. Allen, S. E. Meyer, and D. L. Eggett. 2007. Soil water sensor accuracy for predicting seedling emergence using a hydrothermal time model. Arid Land Research and Management 21:229-243.

Valentine, J. F., And A. R. Stevens. 1994. Use of livestock to control cheatgrassa review. In: S. B. Monsen and S. G. Kitchen [Compilers]. Proceedings-
Ecology and Management of Annual Rangelands; 18-22 May 1992. Ogden, UT: USDA Forest Service Intermountain Research Station, General Technical Report INT-GTR-313. p. 202-206.

Whisenant, S. G. 1990. Changing fire frequencies on Idaho's Snake River Plains: ecological and management implications. In: E. D. McArthur, E. M. Romney, S. D. Smith, and P. T. Tueller [CompILERs]. Proceedings-Symposium on Cheatgrass Invasion, Shrub Die-off and Other Aspects of Shrub Biology and Management; 5-7 April 1989. Ogden, UT: USDA Forest Service Intermountain Research Station General Technical Report INT-276. p. 4-10.

Whisenant, S. G., C. J. Scifres, and D. N. Ueckert. 1984. Soil water and temperature response to prescribed burning. Great Basin Naturalist 44:558-562.

WHITTAKER, A. 2006. Soil water availability of big sagebrush communities in relation to disturbance and elevation [thesis]. Provo, UT: Brigham Young University. $31 \mathrm{p}$.

Wilson, A. M., D. E. Wondercheck, and C. J. Goebel. 1974. Responses of range grass seeds to winter environments. Journal of Range Management 27:120-122.

Wisdom, M. J., M. M. Rowland, and L. H. SuRing [eds.]. 2005. Habitat threats in the sagebrush ecosystem: methods of regional assessment and applications in the Great Basin. Lawrence, KS: Alliance Communications Group. 308 p.

Young, J. A., And R. A. Evans. 1975. Germinability of seed reserves in a big sagebrush community. Weed Science 23:358-364.

Young, J. A., And R. A. Evans. 1978. Population dynamics after wildfire in sagebrush grasslands. Journal of Range Management 31:283-289.

Young, J. A., and R. A. Evans. 1985. Demography of Bromus tectorum in Artemisia communities. In: J. White [ED.]. The population structure of vegetation. Dordrecht, Netherlands: Dr. W. Junk Publishers. p. 489-502.

Young, J. A., R. A. Evans, and R. E. Eckert. 1969. Population dynamics of downy brome. Weed Science 17:20-26. 